\title{
Carvacrol Derivatives with Potential Insecticidal Activity ${ }^{\dagger}$
}

\author{
Carolina M. Natal ${ }^{1}$, David M. Pereira ${ }^{2}$, Renato B. Pereira ${ }^{2}$, Maria José G. Fernandes ${ }^{1}$, A. Gil Fortes ${ }^{1}$, \\ Elisabete M. S. Castanheira ${ }^{3}$ and M. Sameiro T. Gonçalves ${ }^{1, *}$
}

1 Centre of Chemistry (CQ/UM), University of Minho, Campus of Gualtar, 4710-057 Braga, Portugal; carolinanatal.97@gmail.com (C.M.N.); mjfernandes@quimica.uminho.pt (M.J.G.F.); gil@quimica.uminho.pt (A.G.F.)

2 REQUIMTE/LAQV, Laboratory of Pharmacognosy, Department of Chemistry, Faculty of Pharmacy, University of Porto, R. Jorge Viterbo Ferreira, 228, 4050-313 Porto, Portugal; dpereira@ff.up.pt (D.M.P.); ren.pereira@gmail.com (R.B.P.)

3 Centre of Physics (CFUM), University of Minho, Campus of Gualtar, 4710-057 Braga, Portugal; ecoutinho@fisica.uminho.pt

* Correspondence: msameiro@quimica.uminho.pt

+ Present at the 24th International Electronic Conference on Synthetic Organic Chemistry, 15 November 202015 December 2020; Available online: https://ecsoc-24.sciforum.net/.

Citation: Natal, C.M.; Pereira, D.M.; Pereira, R.B.; Fernandes, M.J.G.; Fortes, A.G.; Castanheira, E.M.S.; Gonçalves, M.S.T. Carvacrol Derivatives with Potential Insecticidal Activity. Chem. Proc. 2021, 3, 37. https://doi.org/ 10.3390/ecsoc-24-08334

Academic Editors: Julio A. Seijas and M. Pilar Vázquez-Tato

Published: 14 November 2020

Publisher's Note: MDPI stays neutral with regard to jurisdictional claims in published maps and institutional affiliations.

Copyright: (C) 2020 by the authors. Licensee MDPI, Basel, Switzerland. This article is an open access article distributed under the terms and conditions of the Creative Commons Attribution (CC BY) license (http://creativecommons.org/licenses /by/4.0/).

\begin{abstract}
Three new carvacrol derivatives 1-3 possessing aliphatic carbon chains with different sizes as hydroxyl group substituents were synthesized in order to evaluate their insecticidal activity against the insect cell line Sf9 (Spodoptera frugiperda).
\end{abstract}

Keywords: carvacrol; biopesticides; green insecticides; natural products; Spodoptera frugiperda

\section{Introduction}

Synthetic pesticides have been used for decades to manage pest control in crops, in order to avoid considerable damage and production losses due to pathogens, insects and other pest species [1,2]. Nowadays, because of environmental and health issues, synthetic pesticides are being gradually replaced by botanical pesticides [2,3].

An alternative to pest control is the use of essential oils (EOs) and their major chemical constituents [4]. Essential oils plants' secondary metabolites of low molecular weight and strong organoleptic properties have been investigated as resources of potentially useful bioactive compounds, and it is known that they have an important role in the interactions between insects and plants [5,6]. Carvacrol (2-methyl-5-(1-methylethyl) phenol) is found in the essential oils of thyme (Thymus vulgaris), marjoram (Origanum majorana), oregano (Origanum vulgari L.), pepperwort (Lepidium sp.), and Alaskan yellow cedar (Callitropsis nootkatensis (D. Don) Oerst. ex D. P. Little) [7]. It is a phenolic compound that displays antimicrobial, antifungal, and insecticidal activities $[8,9]$.

Considering these facts, the present investigation is focused on the synthesis of new carvacrol derivatives possessing aliphatic carbon chains with different sizes as hydroxyl group substituents, and their insecticide activity against the insect cell line Sf9 (Spodoptera frugiperda) was evaluated.

\section{Materials and Methods}

\subsection{Typical Procedure for Carvacrol Derivatives 1-3 (Illustrated for 1)}

To a solution of 5-isopropyl-2-methylphenol $(0.105 \mathrm{~mL}, 1$ eq.) in acetonitrile $(4 \mathrm{~mL})$ was added cesium carbonate $(1.0885 \mathrm{~g}, 5$ eq. $)$ and 1 -bromopropane $\left(6.7 \times 10^{-2} \mathrm{~mL}, 1.1\right.$ eq. $)$, and the reaction mixture was heated at $65^{\circ} \mathrm{C}$ with stirring for $24 \mathrm{~h}$. The progress of the reaction was monitored by thin-layer chromatography (TLC) (silica: dichloromethane). The reaction mixture was filtered, washed with acetonitrile and then the solvent was 
evaporated. 4-Isopropyl-1-methyl-2-propoxybenzene was obtained as an orange oil $\left(0.0693 \mathrm{~g} ; 54 \%\right.$ yield). $R_{\mathrm{f}}=0.56$ (petroleum ether). ${ }^{1} \mathrm{H} \mathrm{NMR}\left(\mathrm{CDCl}_{3}, 400 \mathrm{MHz}\right): \delta \mathrm{H} 1.12(3 \mathrm{H}$, $\left.\mathrm{t}, J 7.6 \mathrm{~Hz}, \mathrm{O}\left(\mathrm{CH}_{2}\right)_{2} \mathrm{CH}_{3}\right), 1.30\left(6 \mathrm{H}, \mathrm{d}, J 6,8 \mathrm{~Hz}, \mathrm{CH}\left(\mathrm{CH}_{3}\right)_{2}\right), 1.84-1.93(2 \mathrm{H}, \mathrm{m}$, $\left.\mathrm{OCH}_{2} \mathrm{CH}_{2} \mathrm{CH}_{3}\right), 2.26\left(3 \mathrm{H}, \mathrm{s}, \mathrm{CH}_{3}\right), 2.88-2.95\left(1 \mathrm{H}, \mathrm{m}, \mathrm{CH}\left(\mathrm{CH}_{3}\right)_{2}\right), 3.99(2 \mathrm{H}, \mathrm{t}, \mathrm{J} 6 \mathrm{~Hz}$, $\left.\mathrm{OCH}_{2} \mathrm{CH}_{2} \mathrm{CH}_{3}\right), 6.75(1 \mathrm{H}, \mathrm{d}, J 1.2 \mathrm{~Hz}, \mathrm{H}-3), 6.78(1 \mathrm{H}, \mathrm{dd}, J 7.6 \mathrm{~Hz}, J$ 1.6, H-5), $7.11(1 \mathrm{H}, \mathrm{d}, J$ $7.2 \mathrm{~Hz}, \mathrm{H}-6)$ ppm. $\left.{ }^{13} \mathrm{C} \mathrm{NMR}\left(\mathrm{CDCl}_{3}, 100.6 \mathrm{MHz}\right): \delta \mathrm{c} 10.68\left(\mathrm{O}_{\left(\mathrm{CH}_{2}\right)}\right)_{2} \mathrm{CH}_{3}\right), 15.77\left(\mathrm{CH}_{3}\right), 22.80$ $\left(\mathrm{OCH}_{2} \mathrm{CH}_{2} \mathrm{CH}_{3}\right), 24.13\left(\mathrm{CH}\left(\mathrm{CH}_{3}\right)_{2}\right), 34.14\left(\mathrm{CH}\left(\mathrm{CH}_{3}\right)_{2}\right), 69.36\left(\mathrm{OCH}_{2} \mathrm{CH}_{2} \mathrm{CH}_{3}\right), 109.45(\mathrm{C}-3)$, 117.76 (C-5), 124.13 (C-1), 130.32 (C-6), 147.79 (C-4), 157.15 (C-2) ppm.

\subsection{Cell Culture}

Spodoptera frugiperda cells ( $S f 9$ cell line) were maintained as a suspension culture and cultivated in Grace's medium with 10\% FBS (fetal bovine serum) and 1\% penicillin/streptomycin, at $28{ }^{\circ} \mathrm{C}$. Cells were kept in a humidified atmosphere of $5 \% \mathrm{CO}_{2}$.

\subsection{Viability Assessment}

For the assessment of viability, a resazurin-based method was used. Sfg cells were plated at a density of $3.0 \times 10^{4}$, incubated for $24 \mathrm{~h}$ and then exposed to the molecules under study for $24 \mathrm{~h}$. After this period, a commercial solution of resazurin was added (1:10) and the kinetic reaction of fluorescence increase was monitored at 560/590 nm, with the results being used after 60 min of incubation.

\section{Results and Discussion}

\subsection{Synthesis of Carvacrol Derivatives 1-3}

Carvacrol derivatives 1-3 were synthesized by $O$-alkylation of carvacrol using alkyl halides possessing carbon chains of various sizes. Starting from carvacrol (5-isopropyl-2-methylphenol) and reacting with 1-bromopropane, 1-bromooctane or 1-bromododecane, in the presence of cesium carbonate as a base, at $65^{\circ} \mathrm{C}$ in acetonitrile, 4-isopropyl-1-methyl-2-propoxybenzene 1, 4-isopropyl-1-methyl-2-(octyloxy)benzene 2 and 2-(dodecyloxy)-4-isopropyl-1-methylbenzene 3 were obtained, respectively, as oils in $54 \%-62 \%$ yields (Figure 1 ).

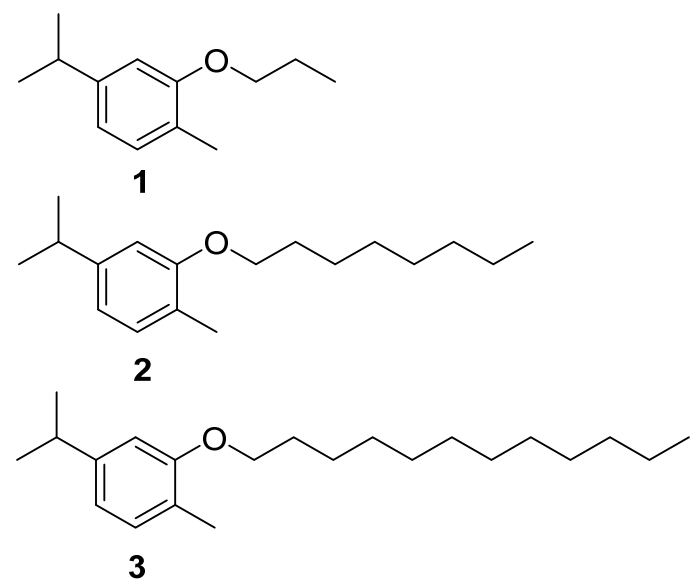

Figure 1. Carvacrol derivatives 1-3.

The ${ }^{1} \mathrm{H}$ NMR spectra of compounds 1-3 showed the different characteristic signals for the protons of methylene $(\delta 1.35-4.00 \mathrm{ppm})$ and methyl groups $(\delta 0.90-1.12 \mathrm{ppm})$ of aliphatic chains, the methyl $(\delta 2.23-2.29 \mathrm{ppm})$ and isopropyl group of carvacrol $(\delta 1.28$ 1.35 and 2.85-3.00 ppm), as well as protons of the aromatic ring H-3, H-5 and H-6 as singlet or duplet $(\delta 6.73-6.78 \mathrm{ppm})$, double doublet $(\delta 6.75-6.82 \mathrm{ppm})$ and duplet $(\delta 7.08-7.15$ $\mathrm{ppm})$, respectively. ${ }^{13} \mathrm{C}$ NMR spectra of all compounds showed the signals of methylene groups $(\delta 22.68-31.93 \mathrm{ppm})$, being signals of $\mathrm{OCH}_{2}$ at higher chemical shifts $(\delta 67.83-$ 
$69.36 \mathrm{ppm})$, methyl groups of aliphatic chains $(\delta 10.68-14.11 \mathrm{ppm})$, as well as methyl ( $\delta$ $15.77-15.81 \mathrm{ppm}$ ) and isopropyl ( $\delta 24.13$ and $34.14-34.16 \mathrm{ppm}$ ) groups of carvacrol moiety, in addition to carbons of the aromatic ring ( $\delta 109.39-157.19 \mathrm{ppm})$.

\subsection{Impact of Carvacrol Derivatives 1-3 in Cell Viability}

The impact of carvacrol derivatives 1-3 in the viability of Sf9 cells was evaluated at $100 \mu \mathrm{g} / \mathrm{mL}$, following 24h of exposure. As shown in Figure 2, the molecules were mostly devoid of toxicity, the exception being 2 that elicited a small reduction in viability, around $20 \%$.

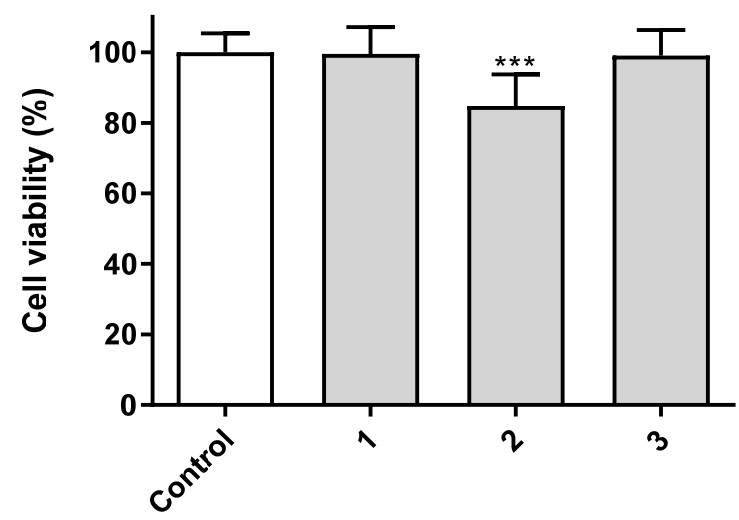

Figure 2. Viability of Spodoptera frugiperda (Sf9) cells after incubation with the indicated molecules $(100 \mu \mathrm{g} / \mathrm{mL})$ for $24 \mathrm{~h}$.

\section{Conclusions}

Three new carvacrol derivatives possessing aliphatic carbon chains with different sizes as hydroxyl group substituents were synthesized. The evaluation of their impact in cell viability showed that medium size carbon chains may have some impact on the cell viability of Sf9. Other carvacrol derivatives are being synthesized in order to continue the evaluation of its effect in mixtures with active compounds as potential insecticides.

Author Contributions: Conceptualization, M.S.T.G. and D.M.P.; methodology, M.S.T.G., D.M.P., and R.B.P.; formal analysis, M.J.G.F., M.S.T.G., D.M.P., and R.B.P.; investigation, C.M.N., D.M.P., and R.B.P.; supervision: M.S.T.G. and D.M.P.; writing-original draft preparation, C.M.N., M.J.G.F., M.S.T.G., and D.M.P.; writing-review and editing, C.M.N., M.S.T.G., D.M.P., A.G.F., E.M.S.C., and R.B.P.; project administration, M.S.T.G. All authors have read and agreed to the published version of the manuscript.

Funding: FCT under project PTDC/ASP-AGR/30154/2017 (POCI-01-0145-FEDER-030154) of COMPETE 2020, co-financed by FEDER and EU. FCT- Portugal and FEDER-COMPETE/QREN-EU for financial support to the research centers CQ/UM (UIDB/00686/2020), CF-UM-UP (UIDB/04650/2020) and REQUIMTE (UIDB/50006/2020). The NMR spectrometer Bruker Avance III 400 (part of the National NMR Network) was financed by FCT and FEDER.

Conflicts of Interest: The authors declare no conflict of interest.

\section{References}

1. Oliveira, J.L.; Campos, E.V.R.; Fraceto, L.F. Recent developments and challenges for nanoscale formulation of botanical pesticides for use in sustainable agriculture. J. Agric. Food Chem. 2018, 66, 8898-8913, doi:10.1021/acs.jafc.8b03183.

2. Fountain, E.D.; Wratten, S.D. Conservation biological control and biopesticides in agricultural. In Encyclopedia of Ecology, $2^{\text {nd }}$ ed.; Fath, B., Ed.; Elsevier: Amsterdam, 2013; Volume 1, pp. 377-381, doi:10.1016/B978-0-12-409548-9.00539-X.

3. Bendre, R.; Bagul, S.; Rajput, J. Carvacrol: An excellent natural pest control agent. Nat. Prod. Chem. Res. 2018, 6, 1-3, doi:10.4172/2329-6836.1000349. 
4. Magierowicz, K.; Górska-Drabik, E.; Sempruch, C. The insecticidal activity of Satureja hortensis essential oil and its active ingredient -carvacrol against Acrobasis advenella (Zinck.) (Lepidoptera, Pyralidae). Pestic. Biochem. Physiol. 2019, 153, 122-128, doi:10.1016/j.pestbp.2018.11.010.

5. Mossa, A.H. Green pesticides: Essential oils as biopesticides in insect-pest Management. J. Environ. Sci. Technol. 2016, 9, 354378, doi:10.3923/jest.2016.354.378.

6. Isman, M.B. Botanical insecticides: A global perspective. In Biopesticides: State of the Art and Future Opportunities; Gross, A.D., Coasts, L.R., Duke, S.O., Seiber, J.N., Eds.; American Chemical Society: Washington, DC, USA, 2014; Volume 1172, pp. 21-30, doi:10.1021/bk-2014-1172.ch002.

7. Campos, E.V.R.; Proença, P.L.F.; Oliveira, J.L.; Pereira, A.E.S.; Ribeiro, L.N.M.; Fernandes, F.O.; Gonçalves, K.C.; Polanczyk, R.A.; Pasquoto-Stigliani, T.; Lima, R.; et al. Carvacrol and linalool co-loaded in $\beta$-cyclodextrin-grafted chitosan nanoparticles as sustainable biopesticide aiming pest control. Sci. Rep. 2018, 8, 1-14, doi:10.1038/s41598-018-26043-x.

8. Youssefi, M.R.; Tabari, M.A.; Esfandiari, A.; Kazemi, S.; Moghadamnia, A.A.; Sut, S.; Dall'Acqua, S.; Benelli, G.; Maggi, F. Efficacy of two monoterpenoids, carvacrol and thymol, and their combinations against eggs and larvae of the West Nile Vector Culex pipiens. Molecules 2019, 24, 1-11.

9. Friedman, M. Chemistry and multibeneficial bioactivities of carvacrol (4-isopropyl-2-methylphenol), a component of essential oils produced by aromatic plants and spices. J. Agric. Food Chem. 2014, 62, 7652-7670, doi:10.1021/jf5023862. 